\title{
Impact of Human Resource Quality and Bureaucracy Behaviour on Organizational Performance Effectiveness
}

\author{
Samiruddin $^{1}$, Yasir Syam Husain ${ }^{2}$ \\ ${ }^{1}$ Halu Oleo University, Department of Administration Science Fakulty of Social and Politic Science and Sosial, Kendari, Southeast \\ Sulawesi, Indonesia
}

Hasanuddin University, Department of Government Politic Science, Faculty of Social and Politic Science, Makassar, Southeast Sulawesi, Indonesia

${ }^{2}$ Halu Oleo University, Doctoral Program of Management Science, Kendari, Southeast Sulawesi, Indonesia

\begin{abstract}
This research was conducted to exam the relationships of human resources quality and bureaucracy behaviour on organizational performance effectiveness both in parcially and simultaneously. It was based on explanative survey of 72 employees and Proportionate Stratified Random Sampling was used to classify them in fourth level. Quantitative research was also used to analyze the data with Structural Equation Modeling (SEM) in regression and path analysis. The result revealed that human resources quality had a significant effect on effectiveness of organization performance. Having knowledge was the main reason for employess that determining their human resource quality. It was also showed that bureaucracy behaviour had a significant effect on effectiveness of organization performance. Expectiveness was the main reason for employess that determining their human resource quality. In Simultaneously, both human resources quality and bureaucracy behaviour had a significant effect on effectiveness of organization performance.Thus, the factors of having knowledge and expectiveness were the most factor that contributed to effectiveness of organization performance so that it was suggested to maintain the existing of these factors.
\end{abstract}

Keywords: Human Resources Quality, Bureaucracy Behaviour, Organizational Performance Effectiveness, Indonesia

\section{Introduction}

Starting from the reform era in 1998, in which the Indonesian people have previously been exposed to various regional crises globally that cannot be separated from the failure to develop governance and management system development based on the principles of good Governance. This is reflected in the performance of public sector organizations are often described unproductive and inefficient, so many people are because it is considered unsatisfactory. The public dissatisfaction on the performance of government officials in obtaining services due in obtaining services is caused to rigid bureaucracy and slowly performance. (LAN 2011: 15)

Observing the current condition of the government bureaucracy, Peter Drucker (2006: 86) highlighted that "actually that no nation is poor or underdeveloped, it is only a nation unmanaged with good". Peter Drucker thought, it can be used as a foothold hypotheses about the causes of crisis, particularly in negatives brand image attached to the government bureaucracy.

The problems of the current government bureaucracy is not out of the low quality of personnel resources, morale and awareness of duties and responsibilities of a low, weak coordination function; bureaucratic organizations are severely obese; the high culture of corruption; and a low level of understanding on his duties as a public servant. This is illustrated by the results of a survey conducted by international agencies, where they put the Indonesian government bureaucracy in a very bad position compared to other countries. The survey is conducted by the Political and
Economic Risk Consultancy (PERC), the results shows that the Indonesian government bureaucracy at worst the second ranking position in terms of investments at the level of Asian countries in 2006, (Kompas, May 26, 2006).

At this level of performance improvement of public service bureaucracy becomes an increasingly strategic issue, because it has broad implications in the lives of both in central and local communities, particularly in improving the level of public confidence in the government. Human resources (HR) are a supporting factor that greatly affects an organization. In addition to the quality of personnel resources, other factors that also affect the effectiveness of the organization's performance is bureaucratic behavior. Where in carrying out its activities need to be supported by the behavior of its members based on the interests of the organization, but it also can satisfy the individual interests of the employees, so it can achieve the organizational goals. Based on the explanation that has been mentioned above, it can be concluded that the causative factor which obtained ineffectively organizational performance is not yet fully done professionally.

\section{Literature Review}

\section{Organizational Performance Effectiveness}

Studies on the effectiveness refer to the two interests that are both theoretically and practically. Richard M.Steers offers five criteria in measuring the effectiveness of the organization. They are productivity, adaptability or flexibility, job satisfaction, ability gainful and searching resources (Steers, 1985: 205). Meanwhile, according to Gibson said also that the effectiveness of the organization

\section{Volume 5 Issue 2, February 2016}




\section{International Journal of Science and Research (IJSR) \\ ISSN (Online): 2319-7064}

Index Copernicus Value (2013): 6.14 | Impact Factor (2014): 5.611

can also be measured as follows: clarity of objectives to be achieved; clear strategic goal attainment; process analysis and formulation of policy steady; careful planning; the preparation of appropriate programs; the availability of infrastructure; monitoring and control systems that are educational (In Siagian, Sondra, P, 1998: 30).

In the implementation, the performance of public organizations, Salim and Woodward (1992) view performance as considerations of economy, efficiency, effectiveness and equity of service. In this context, the economic aspect is defined as a strategy for using the fewest possible resources in the process of public service activities. The efficiency of public service performance is also seen to designate a condition to achieve the best ratio (proportional) between the inputs to the output of services. Similarly, the effectiveness of aspects of service performance is to see the achievement of compliance objectives or targets that have already been determined. The principle of fairness in the provision of public services is also seen as a measure to assess how much a form of ministry has been considering the aspects of justice and to make the public have equal access to the services provided by the system. Thus, to measure the quality of personnel resources, it is used on productivity, quality of Service and responsiveness.

\section{Human Resources Quality}

Armstrong stated that human resources are the most important assets for an organization. Therefore he should get serious attention so that the organization's objectives can be achieved in line with expectations. (Armstrong, 1998: 1). There are four aspects contained in the resource development of personnel as proposed by Bryant and White that includes "capacity, equity, empowerment and sustainability" (Bryant and White, 1989: 15).

In a learning organization which needs to be developed was to get every member of the organization to think in a systematic way, do not think individually or fragmented. Since, in every member of the organization basically has the same goal of achieving organizational goals (Etzioni: 1992: 7). Hersey and Blanchard (1993: 8) argues that there are at least three necessary skills possessed by each employee so that the management can take place in a rational, effective, and efficient. The third skill is the skill of the technique: humanitarian and conceptual. Because it was the third power that should be possessed are technical skills, human skills and conceptual skills so that the bureaucrats were able to carry out the management process in a rational, effective and efficient.

If it is associated with the service, then the performance of the regional government is influenced by two (2) factors of competence (ability) and motivation of personnel, while the performance of local governments can be seen from the aspect of "productivity, quality of service, responsiveness, responsibility and accountability" (Livine et. al, 1990: 113). The object of personnel resource development proposed by Maryoto is to "improve the effectiveness and efficiency of their work in implementing and achieving the program objectives or goals of the organization" (Martoyo, 2000: 68). The foregoing can be achieved through: (1) knowledge, (2) Skills; (3) The attitude towards their duties. Humans are the main resource organization that cannot be replaced by other resources. Siagian (1997: 152) states that: "There is no denying also that manpower or human resources are the most important resources that may be owned by an organization". The same thing also delivered by Indrawijaya (2002: 27), that: "However good organization, full facilities and working facilities, everything would have no meaning without the man who set up, use and maintain."

In the context of the quality of personnel resources, decentralization, according to Eng Koswara (2001: 266-267) states that the ability of professional and technical skills of the employees, including the staff and implementing elements within local government is urgently needed so that government management in autonomy can take place effectively and efficiently. What is needed is not only sufficient in number, but also the quality of the employees that should be measured by looking at the educational background, skills, work experience, ladder and employment status. Based on the opinions, the meaning of the quality of human resources is the level of education, experience, knowledge and skills required to carry out tasks that are the responsibility of members in order to achieve organizational goals. Thus, to measure the quality of personnel resources, it is used on education; experience; knowledge; and skills.

Harris et al. (2007) whom conducting a research in health sector found that human resources management (HRM) has have a relationships toward policies system and performance. It is supported by several recent reviews stated that HR practices or systems of HR practices are linked to individual and organisational performance (e.g. Boselie et al., 2005; Combs et al., 2006; Hyde et al., 2006; Wall and Wood, 2005). Boohene and Asuinura (2011) investigate to corporate performance. They found that there exists a positive relationship between effective recruitment and selection practices, effective performance appraisal practices and GCGL's corporate performance. The research did not gather sufficient evidence to conclude on how remuneration, training and development practices influence GCGL's performance. Thus, it's proposed the hypotheses as follows:

H1: Quality of human resources has affect significantly on effectiveness of organizational performance

\section{Bureaucracy Behavioral}

The study of behavior in government management, is actually an approach that is quite real, emerging around 1950 or after World War II, although the real reaction to the behavior of people in a variety of organizational structures have emerged since the beginning of the 20th century as a response to inequality, conflicts and problems that arise in the interaction of people at every layer of the organization, both public organizations and private organizations. Moreover, Cofer and Appley 1964 (Ivancevich et al, 1977: 19) elaborate the behavior of individuals by using one piece of individual characteristics, namely; motive which is one of component within individual that can affect behavior. Behavior itself is an individual response to the events in the neighborhood. Cofer and Appley further said that according to scientists in the field of behavior, there are two groups of motives divided into two group categories. The first group includes: drives, urges, feelings, forces, instincts, needs, 


\section{International Journal of Science and Research (IJSR) \\ ISSN (Online): 2319-7064}

Index Copernicus Value (2013): 6.14 | Impact Factor (2014): 5.611

desire; wants, emotions, impulse and striving. They encourage a person to act and establish a behavior. The second group which is the factors or events in the environment of individuals includes: incentive, purpose, interest, aspiration. They realize individual expectations that will occur as a result of a behavior or better known as factors attract behavior.

In another perspective, Bryant and White (1989: 27), suggests that there are two models developed with respect to changes in the behavior of individuals in the organization. They were rational model and sociological-psychological model. Rational model is set on the assumption that individuals are rational and have their own personal interests, which do not automatically have voluntarily put aside the personal interests to the interests and the achievement of organizational goals. Sociologicalpsychological model is set on the assumption that changes in individual behavior in organizations are influenced by factors of sociological and psychological that surrounds an organization. It is these factors which later became 'determinant' the major influencing behavioral changes of individuals in the organization, whether that comes from outside, or in the organization itself. It is technology, social structure, event / events, values, attitudes, emotional, and environmental organizations a role in social, economic and political.

According to Siagian (1997: 13) stated that behavior is a "whole person's character and nature which is reflected in the words and acts of horns as a member of an organization is. Thoha (2002: 184) based on the formula of psychology stated that "the behavior is merely the result of interaction between individuals with the organization". Indrawijaya (2002: 34) viewed on the systemic stated that "human behavior is determined by a process of input and output. It means that we must assume that man is an open system, not something that can be isolation and that human integration with the environment and life in the neighborhood ".

The definitions mentioned imply that the concept relating to the behavior of a person's attitude and actions as a result of interaction or reciprocal relationship between an individual and his environment. As for the concept of bureaucratic behavior, according Thoha (2002: 184), is essentially a result of interaction between individual characteristics with the characteristics of bureaucracy. Individuals were carrying characteristics such as ability, personal beliefs, expectations, needs and experiences of the past, while the bureaucracy has its own characteristics such as name hierarchy, division of labor, their powers and responsibilities, the payroll system, and the control system ". Robbins (2006: 7) defines organization behavior is "a field of study that investigates the impact to individuals, groups, and structure as a behavior within organizations for the purpose applying such knowledge to improve the effectiveness of the organization". Furthermore, regarding on the conduct of government bureaucracy, (Eugebe Litwak in Supriatna, 2000: 183) states that behavior is influenced by individual behavior of government bureaucracy both the micro and macro organizational behavior and contrary. The behavior of individuals within the government organization was formed by physiological factors (physical and mental), psychological factors (perception, attitude, personality, learning and motivation), environmental factors (family, cultural and social class). Government bureaucratic behavior is influenced by the status, roles, norms, cohesive, conflict and ambiguity, communication, management, leadership and cooperation in organizational effectiveness. Thus, to measure the bureaucratic behavior, it is used on Needs of employees; self confidence, expectation, hierarchy and control system.

Osman stated that there is significant relationship between employee behavior and job performance. The employee attitude, motivation and absenteeism are important variable in determining positive effects on job performance. This study revealed that employee attitude contributes main player in organization. It's proposed the hypotheses as follows:

$\mathrm{H} 2$ : Bureaucratic behavior has affect significantly on organizational performance effectiveness

H3: Human resources quality and bureaucratic behavior has a significant simultaneous effect on effectiveness of organizational performance

Thus, conceptual framework in this study can be seen in the following Figure.

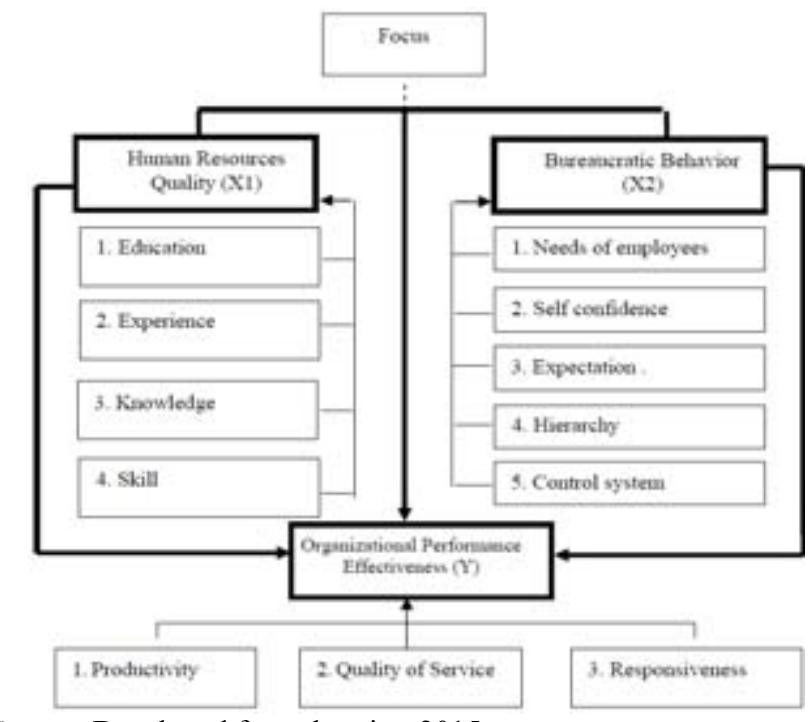

Source: Developed from theories, 2015

Figure 1: Conceptual Framework

\section{Research Methods}

The study design used in this research is explanatory survey design that aims to identify and test the effect of independent variables on the dependent variable. Research samples consisted of 72 participants obtained from 265 people who work as a civil servant in Department of Education and Culture, Southeast Sulawesi province. Proportionate stratified random sampling was used to classify into strata of Employees so that it was selected: 1 official in second level, 2 officials in third level, 4 officials in fourth level, and 65 people were employees. Data was analyzed by using quantitative methods of path analysis technique to analyze the regression and path.

\section{Volume 5 Issue 2, February 2016}




\section{International Journal of Science and Research (IJSR) \\ ISSN (Online): 2319-7064 \\ Index Copernicus Value (2013): 6.14 | Impact Factor (2014): 5.611}

\section{Data Analysis and Result}

This study aims to explain the enormous influence of the human resources quality on the effectiveness of organizational performance, describes the influence of bureaucratic behavior on the effectiveness of organizational performance, and explain the simultaneously influence of the human resources quality and bureaucracy behavior on the effectiveness of organizational performance.

\section{Regression analysis}

Based on the results of regression analysis, the multiple linear regression equation can be determined as follows:

$\mathrm{Y}=\mathrm{a}+\mathrm{b}_{1} \mathrm{X}_{1}+\mathrm{b}_{2} \mathrm{X}_{2}$

$Y=63,640+0,638 X_{1}+0,233 X_{2}$

\section{Regression coefficients}

The regression coefficient is intended to determine the influence of human resource quality and bureaucratic behavior on effectiveness of organizational performance. In accordance with the equation mentioned, it is known that:

$\mathrm{a}=63.640$, meaning that if there is a change of human resource quality and bureaucratic behavior in one unit, the organizational performance effectiveness will be unchanged at 63.640 .

$\mathrm{b} 1=0.638$, meaning that if the human resource quality increased by one unit, the organizational performance effectiveness will increase in 0.638 units with assuming that the other factors is constant

$\mathrm{b} 2=0.233$, meaning that if the bureaucracy behavior increased in one unit, organizational performance effectiveness will increase in 0.233 with assuming that the other factors is constant

\section{Correlation Coefficient ( $r$ )}

Correlation coefficients (r) show that the value of correlation coefficient (r) obtained at 0.741. It means that human resource quality and bureaucratic behavior associated positively and very powerful in improving the effectiveness of organizational performance. It means also that if human resource quality and bureaucratic behavior is improved, the organizational performance effectiveness will also increase.

\section{Determination coefficient ( $r$ square)}

Determination coefficient ( $\mathrm{r}$ square) stated that the value determination coefficient ( $\mathrm{R}$ square) is 0.549 . It shows that the variation changes to organizational performance effectiveness is determined or influenced by the human resources quality and bureaucratic behavior amounted to $54.9 \%$ and the other of $45.1 \%$ is determined by other factors beyond the study models.

\section{T test}

Analysis results using SPSS shows that human resource quality has an effect significant partially on effectiveness of organizational performance. It is shown by the results of ttest at the confidence level of 0.95 or $\alpha=0.05$ which the level of freedom degrees in 69 , where $t_{\text {counted }}=7.466>t_{\text {table }}$ is 1.667 or probability value $=0.000<0.05$. Thus, the first hypothesis (H1) that human resource quality has an effect positive significantly on organizational performance effectiveness that can be acceptable.
Bureaucratic behavior has an effect significant partially on effectiveness of organizational performance. It is shown by the results of t-test at the confidence level of 0.95 or $\alpha=$ 0.05 which the level of freedom degrees in 69 , where $t_{\text {counted }}$ $=2.615>\mathrm{t}_{\text {table }}$ is 1.667 or probability value $=0.000<0.05$. Thus the second hypothesis (H2): human resource quality has an effect positive and significantly on organizational performance effectiveness that can be acceptable. Thus, the second hypothesis assumed that bureaucratic behavior has an effect positive significantly on organizational performance effectiveness that can be acceptable.

F test

Analysis results states that human resource quality and bureaucratic behavior, in simultaneously, has a significant effect on effectiveness of organizational performance. It is indicated that the $\mathrm{F}$ test results on the confidence level of 0.95 or $\alpha=0.05$ with the level of freedom degrees in 69 , which of $\mathrm{F}_{\text {counted }}=41.931>\mathrm{F}_{\text {table }}$ is 3.13 or probabilities value $=0.000<0.05$. It means that the human resources quality and bureaucratic behavior has simultaneously positive and significant impact on the organizational performance effectiveness. Thus, the third hypothesis (H3) assumed that within simultaneously of human resources quality and bureaucratic behavior has a positive effect on the effectiveness of organizational performance, so it was concluded that this hypothesis can be acceptable.

\section{Discussion}

This Study found that human resource quality had a significant positive effect on organizational performance effectiveness. It means that the more human resource quality, the higher of organizational performance effectiveness. Therefore, good in human resource quality will improve organizational performance effectiveness There are four factors inventing of human resource quality for personnel that work in education and culture department. They are knowledge, skill, experience, and education. Having knowledge is the most factors determining so they get an improvement of organizational performance effectiveness

Study reveals that bureaucratic behavior had a significant positive effect on organizational performance effectiveness. It means that the more bureaucratic behavior, the higher of organizational performance effectiveness. Therefore, good in bureaucratic behavior will improve organizational performance effectiveness. There are five factors inventing of bureaucratic behavior for personnel that work in education and culture department. They are expectation, control system, self confidence, hierarchy, and needs. Expectations are the most factors determining so they get an improvement of organizational performance effectiveness.

It resulted also that human resource quality and bureaucratic behavior had a simultaneously significant positive effect on organizational performance effectiveness. It means that the improvement of human resource quality and bureaucratic behavior simultaneously will develop organizational performance effectiveness. Therefore, the contribution of these factors has an important role for organizational performance effectiveness.

\section{Volume 5 Issue 2, February 2016}




\section{International Journal of Science and Research (IJSR) \\ ISSN (Online): 2319-7064}

Index Copernicus Value (2013): 6.14 | Impact Factor (2014): 5.611

\section{Conclusion}

Based on the results, it can be concluded that: firstly, human resource quality has a positive significant effect on organizational performance effectiveness. It means that the more human resource quality, the higher of organizational performance effectiveness. Secondly, bureaucratic behavior has a positive significant effect on organizational performance effectiveness. It means that the more bureaucratic behavior, the higher of organizational performance effectiveness. Finally, human resource quality and bureaucratic behavior had a simultaneously significant positive effect on organizational performance effectiveness. It means that the improvement of human resource quality and bureaucratic behavior simultaneously will develop organizational performance effectiveness.

\section{Limitations and Future Research}

The determination factor of organizational performance effectiveness has still remained another factor that unreachable in this research. Another variable could be also examined as an impact factor of organizational performance effectiveness in future research. The samples of this research were employees in education and culture department so for future research should investigate in another profession. Future research may design a longitudinal study to test the model of organizational performance effectiveness.

\section{References}

[1] Amstrong, M.,1998, A Hand Book of Human Resources Management, PT. Elex Computindo, Jakarta.

[2] Boohene, R., and Asuinura, E.L., 2007. The Effect of Human Resource Management Practices on Corporate Performance: A Study of Graphic Communications Group Limited. International Business Research Vol. 4, No. 1; January 2011.

[3] Boselie, P., Dietz, G. and Boon, C. (2005), "Commonalities and contradictions in HRM and performance research", Human Resource Management Journal, Vol. 15, pp. 67-94.

[4] Bryant, Coralie and Louise G. White. 1989. Depelopment Management for developing Countries, Rusyanto (Penterjemah) manajemen pembangunan untuk negara berkembang. Edisi pertama. LP3ES. Jakarta.

[5] Combs, J., Liu, Y., Hall, A. and Ketchen, D. (2006), "How much do high performance work practices matter? A meta-analysis of their effects on organizational performance", Personnel Psychology, Vol. 59, pp. 501-28.

[6] Drucker, Peter, 1997, Organisasi Masa Depan, (Alih Bahasa Achmad Kemal), Jakarta : Penerbit Elex Media Komputindo Kelompok Gramedia.

[7] Engkoswara. (2001). Paradigma Manajemen Pendidikan Menyongsosng Otonomi Didaerah, Yayasan amal keluarga.

[8] Etzioni, Amitai. Alih Bahasa: Suryatim. 1985. Organisasi-organisasi Modern (terjemahan). Jakarta: UI-Press.
[9] Harris, C., Cortvriend, P., and Hyde, P., 2007. Human resource management and performance in healthcare organizations. Journal of Health Organization and Management Vol. 21 No. 4/5, 2007

[10]pp. 448-459 q Emerald Group Publishing Limited 14777266. DOI 10.1108/14777260710778961

[11] Hersey, Paul dan Ken Blanchard, 1993, Manajemen Perilaku Organisasi, Pendayagunaan Sumber Daya Manusia, Penerjemah : Agus Dharma Jakarta: Penerbit Erlangga.

[12] Hyde, P., Boaden, R., Cortvriend, P., Harris, C., Marchington, M., Pass, S., Sparrow, P. and Sibbald, B. (2006), Improving Health through Human Resource Management, CIPD, London.

[13] Indrawijaya, Adam. 2002, Perilaku Organisasi, Sinar Baru Algensindo, Bandung.

[14] Ivancevich, Jhon M. Andrew D. Szilagyi Jr. and March J Wallace Jr. 1977. Organizational behavior and performance. First edtion. Goodyear publishing com inc.santa monica.

[15]Levine, Charles H., 1990, Public Administration : Challenges, Choices, Consequences, Scott Foreman/Litle Brown Higher Education : Glenview, Illianos.

[16]LAN, BPKP. 2011. Pengukuran kinerja instansi pemerintah, Modul Sosialisasi Sistem Akuntabilitas Kinerja Instansi Pemerintah (AKIP). Lembaga Administrasi Negara. Jakarta.

[17] Kompas, May 26, 2006. Newspaper. Indonesia.

[18] Martoyo, S. (2000), Manajemen Sumber Daya Manusia, BPFE, Yogjakarta.

[19] Osman, I.B., Aminuddin, N.F.B., Md Elias, N.L.B, Ariffin, M.N.A.B. The Effect Of Employee Behavior On Job Performance. University Teknologi Mara (UiTM) Kampus Bandaraya Melaka.

[20] Peter, B. Guy. 1984. American Public Policy. Franklin Watts, New York: Tulano University.

[21]Robbins, Stephen P,.2006. Perilaku Organisasi. Alih Bahasa : Benyamin Molan. Edisi Kesepuluh. PT. Indeks, Kelompok Gramedia, Jakarta.

[22] Salim \& Woodward. 1992. Analisis Pelayanan Publik. Pustaka Pelajar. YogyakartaSagir, Suharsono, 1985, Ekonomi Indonesia Menghadapi Pelita IV. Alumni, Bandung.

[23] Siagian, Sondang P. 1997, Organisasi, Kepemimpinan dan Perilaku Adminisrasi, PT Toko Gunung Agung, Jakarta.

[24] Steers, Richard M.1985, Efektivitas Organisasi (Kaidah Perilaku), Erlangga, Jakarta.

[25] Supriatna, Tjahya, 1997, Administrasi Birokrasi dan Pelayanan Publik, PT. Nimas Multima, Jakarta.

[26] Thoha, Mifta, 2002, Perspektif Perilaku Birokrasi, Dimensi-dimensi Prima Ilmu Administrasi Negara Jilid II, PT. Raja Grafindo Persada, Jakarta.

[27] Wall, T.D. and Wood, S.J. (2005), "The romance of human resource management and business performance, and the case for big science", Human Relations, Vol. 58 , pp. 429-62. 